Милош Н. Стојадиновић Универзитет у Нишу Филозофски факултет Департман за психологију Студент докторских студија
УДК: 17.018.21:37

https://doi.org/10.18485/uzdanica.2020.17.2.15

Оригинални научни рад Примљен: 30. септембар 2020. Прихваћен: 21. децембар 2020.

\title{
ПОВЕЗАНОСТ ИСТРАЈНОСТИ И АКАДЕМСКОГ ПОСТИГНУЋА: МЕТААНАЛИЗА
}

$A \bar{u} c \bar{u} p a \kappa \bar{u}:$ Последњих година конструкт истрајности привлачи пажњу како истраживача тако и практичара из области развојно и образовно психолошких делатности. Истрајност се показала као важан некогнитивни предиктор академског постигнућа, као и постигнућа у разним другим областима. Међутим, емпиријски налази неретко бивају неконзистентни када је веза истрајности и академског постигнућа у питању. Ово истраживање за циљ је имало синтезу емпиријских налаза о повезаности истрајности и академског постигнућа. Двадесет три релевантне студије $(N=16820)$ испуниле су критеријуме укључивања у метаанализу. Статистичка анализа под претпоставком модела варијабилних ефеката упућује на то да постоји умерена повезаност истрајности и академског постигнућа $(r=.226[C I: .138 ; .311], Z=4.958, p<.001)$.

Кључне речи: истрајност, академско постигнуће, метаанализа.

\section{ТЕОРИЈСКИ ОКВИР}

Кључни фактори академског постигнућа деценијама уназад предмет су интензивних психолошких истраживања (Долек, Лажоа 2018; Дакворт и др. 2007; Хуанг, Лим, Ха 2017; Метерн, Шо 2010). Когнитивне способности као што је, на пример, интелигенција, дуго су сматране главним конструктима који би могли описати и објаснити академско постигнуће и који би омогућили његову предикцију. Међутим, последњих петнаестак година многи истраживачи су се оградили од ове перспективе и данас постоји читав талас истраживача из области развојне и ооразовне психологије који заступају мишљење да когнитивне способности саме за себе нису довољне за објашњавање и закључивање о академском постигнућу. На пример, Дакворт и сарадници (Дакворт и др. 2007) налазе да се нивоом интелигенције не може објаснити појава да људи са нижим коефицијентом интелигенције постижу више академске резултате у односу на људе са вишим коефицијентом интелигенције. Истовремено, у неким истраживањима показало се да некогнитивни

milos.stojadinovic@filfak.ni.ac.rs 
фактори, као што су особине личности и ставови, могу објаснити добар део варијансе академског постигнућа (Дату, Валдез 2016; Дакворт, Јигер 2015; Јигер, Волтон 2011). Поред интраиндивидуалних когнитивних и некогнитивних фактора, дискусија о кључним факторима академског постигнућа не би смела изоставити ни бројне спољашње и ситуационе чиниоце који и те како могу имати удела у варијанси академског постигнућа (Остин, Саклофски, Масторас 2010; Дада, Бабатунде, Аделеје 2019; Фук, Сиду 2015; Сохејл, 2013).

Последњих година истраживачи придају значај исиирајносиии (енгл. grit) као конструкту који би могао имати значаја у објашњавању и предикцији академског постигнућа. Поготово се овај конструкт показао значајним када је у питању академско постигнуће ученика који се нешто теже носе са свим школским изазовима. Поред ученика, предмет истраживања са аспекта истрајности били су и наставници (Дакворт, Квин, Селиџмен 2009). Улога истрајности испитивана је и на радном месту (Сузуки и др. 2015), али и унутар многих других организационих средина (Лам, Жу 2019).

Истрајност је као истраживачки конструкт први пут предложен 2007. године од стране професорке Енџеле Ли Дакворт и сарадника (Дакворт и др. 2007) и од тада су спроведена бројна истраживања у настојању да се он боље испита и одреди. Донекле се усталила дефиниција истрајности као постојаности и страствености у односу на дугорочне циљеве, при чему су битна три кључна елемента: (1) јасни циљеви којима појединац тежи; (2) континуирано залагање и труд усмерен ка циљевима; (3) посвећеност и страственост у вези с циљевима. На основу тога, исти аутори (Дакворт и др. 2007) нуде и нешто прецизнију дефиницију истрајности као конзисиенийносиии иниеересована

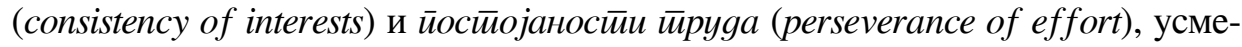
рених ка остварењу одређеног циља. Дакле, реч је о једном сложеном конструкту за који се може рећи да се налази негде на „ничијој земљи” између чисто когнитивних и чисто некогнитивних фактора академског постигнућа.

Треба напоменути да све већи број аутора налази незанемарљиве сличности између истрајности и других психолошких (углавном некогнитивних) конструката као што су самоконтрола (Ориол и др. 2017), саморегулација (Муенкс и др. 2017), интринзичка мотивација (Чен 2018), одважност (Мади и др. 2013) и други. Такође, уочена су преклапања конструкта истрајности и неких особина личности, међу којима се посебно издваја савесност из Big Five модела (Кели и др. 2018). Аутори конструкта истрајности одговарају на ову критику наводећи да се истрајност разликује по томе што се односи на циљеве релативно дугорочне природе, док се други конструкти, на пример самоконтрола и саморегулација, више тичу тренутних, свакодневних и успутних дистракција (Дакворт, Грос 2014). Спроведена су и емпиријска истраживања која су пружила поприлично чврсте доказе за разликовање истрајности од самоконтроле (Крид, Тинан, Хармс 2017). 
Истрајност је испрва најчешће била мерена Grit-O скалом која ce caстоји од 12 ставки (Original Grit Scale - Grit-O; Дакворт и др. 2007). Међутим, у више наврата се показало да овај инструмент постиже ниске индексе уклапања у модел при конфирматорној факторској анализи и да, уопште гледано, нема задовољавајућа психометријска својства. Нешто касније је развијена Grit-S (Grit Scale - Grit-S; Дакворт, Квин 2009), која има осам ставки и показује далеко боља психометријска својства. Оно што је заједничко за обе скале јесте да се истрајност третира као конструкт вишег реда који је сачињен од два предмета мерења - (1) конзистентности интересовања и (2) постојаности труда. Овакав теоријски модел који претпоставља двофакторску структуру истрајности подржан је већим бројем студија, како квантитативних тако и квалитативних (Кристенсен, Кнезек 2014; Дазу, Јуен, Чен 2018; Ли и др. 2018).

Истрајност се више пута показала статистички значајним предиктором академског постигнућа (Ејкос, Кречмер, 2017; Козгроув, Чен, Кастели 2018; Дакворт, Квин 2009; Хоџ, Рајт, Бенет 2018), али постоје и истраживања која су пружила доказе о изостанку предиктивне моћи истрајности када је академско постигнуће у питању (Ал-Мутава, Фател 2018). Овакве повремене противречности налаза јесу оно што налаже даље и дубље проучавање конструкта истрајности.

Занимљиви су налази који показују да две компоненте истрајности - конзистентност интересовања и постојаност труда - имају неистоветни ефекат при различитим фазама и врстама учења. Тако, на пример, Волтерс и Хусеин (Волтерс, Хусеин 2015) закључују да је постојаност труда добар предиктор многих компоненти саморегулације у учењу, док конзистентност интересовања има не само далеко мању предиктивну моћ када је саморегулација учења у питању, већ је и њен опсег дејства мањи. С друге стране, Штурман и Запала-Пиеме (Штурман, Запала-Пиеме 2017) налазе да конзистентност интересовања, у поређењу са постојаношћу труда, остварује много већи ефекат на постигнуће ученика на тесту математике. Ова специфичност дејства још је један рационалан разлог за даље проучавање конструкта истрајности.

Налази засновани на испитивању конструктне ваљаности истрајности, такође, упућују на закључак да узраст ученика (односно разред) може имати модераторску улогу када је однос истрајности и академског постигнућа у питању (Лам, Жу 2019), а исти аутори примећују да на величину ефекта који истрајност има на академско постигнуће може утицати и сам начин мерења академског постигнућа, односно мера преко које се академско постигнуће операционализује.

Конструкт истрајности добио је последњих десетак година на значају када је образовна пракса у питању. Међутим, то не мора нужно значити и емпиријски доказану повезаност истрајности и академског постигнућа. Овај 
рад има за циљ да провери да ли постоје емпиријске потврде о повезаности истрајности и академског постигнућа. У вези с тим формулисана је и главна истраживачка хипотеза која се тестира у оквиру овог синтетичког истраживања:

- $\mathrm{H}_{\mathrm{G}}$ : Постоји умерена повезаност истрајности и академског постигнућа код ученика различитих узраста, односно ученика различитих нивоа школовања.

На енглеском говорном подручју као репрезентативни примери издвајају се два рада који сумативно испитују однос истрајности и академског постигнућа и представљају својеврсне комбинације прегледних радова и метаанализа - један је рад Крида и сарадника из 2017. године (Крид, Тинан, Хармс 2017), а други је рад Лама и Жуа из 2019. године (Лам, Жу 2019).

У овом раду испитивана је повезаност истрајности уопште, без залажења у специфичне односе њених засебних компоненти (конзистентности интересовања и постојаности труда) са академским постигнућем.

\section{МЕТОДОЛОШКИ ПРИСТУП}

\section{ПОТРАГА ЗА ПРИМАРНИМ ИЗВОРИМА И КРИТЕРИЈУМИ ПОДОБНОСТИ СТУДИЈА}

Претрага примарних извора вршена је крајем јула 2020. године. Стратегија претраге подразумевала је систематску потрагу за студијама помоћу сервиса Google Scholar, са фразом 'grit academic OR educational achievement OR performance OR success'. То значи да су кључне речи биле (1) grit, (2) academic или educational и (3) achievement или performance или success. Оваква стратегија одабрана је због релативно једнаке заступљености свих наведених термина у савременој психолошкој литератури. Критеријум за престанак даље претраге био је три узастопне странице без релевантних резултата на претраживачу Google Scholar.

Код свих радова, најпре су анализирани наслов, кључне речи и апстракт. Они радови који би се на основу овог прелиминарног таласа анализе показали подобним, били су анализирани у целини, под условом да им је било могуће приступити без плаћања.

Овом метаанализом обухваћена су рецензирана примарна истраживања објављена у научним часописима који су индексирани на SCImago листи и који су објављени од јануара 2016. године до јула 2020. године. Утврђени су следећи критеријуми подобности истраживања: (1) Укључене су студи- 
је са узорцима ученика (под овим се подразумевају и студенти свих нивоа студија) свих узраста и образовних нивоа, без обзира на њихов пол, расу и друге демографске карактеристике. (2) Укључене су студије које истрајност мере помоћу Grit-S или Grit-O скале. Друге мере новијег датума (и најчешће невалидиране) изостављене су при овој конкретној метаанализи. (3) Подобним мерама академског постигнућа сматране су просечна оцена и њени деривати (grade point average - GPA; Ричардсон, Ајбрехем, Бонд 2012), односно показатељи академског постигнућа који се израчунавају на основу просечног постигнућа у (а) свим академским предметима или (б) неколико фундаменталних академских предмета ${ }^{1}$. У обзир су узете званичне информације о просечној оцени преузете из различитих институционалних база података, као и самоискази (self-reports) испитаника о њиховој просечној оцени. У метаанализу нису укључене студије у којима су коришћене разне субјективне мере академског постигнућа, које су, узгред речено, све више присутне у истраживањима.

Студије су биле укључене у метаанализу уколико је њихов предмет истраживања повезаност између истрајности и академског постигнућа код ученика. Најпре су детаљно анализирани апстракти радова. Уколико је на основу апстракта било очигледно да је конкретан рад неподобан за потребе ове метаанализе, рад је бивао искључен из даљег разматрања. Уколико се рад на основу садржаја апстракта уклапао у тему метаанализе, бивао је укључен и касније се приступало анализи целовитог текста рада. Када се на основу првог увида у апстракт рада није могао стећи потпуни утисак о томе да ли је рад прикладан за метаанализу или не, свакако се приступало анализи целог текста и након тога се доносила одлука о његовој подобности. Радови код којих се и након увида у целовит текст није без недоумица могла оценити подобност остављени су за поновну анализу након анализе других радова.

\section{КОДИРАЮЕ И ОБРАДА ПОДАТАКА}

Кодирање и обрада података спроведени су помоћу програма Microsoft Excel 2013 и IBM SPSS Statistics 20. Величина узорка и величина ефекта (поред осталих релевантних података) из сваке студије унесене су у матрицу. Величине ефеката у свим студијама које су укључене у метаанализу биле су изражене неким од коефицијената корелације, који се уопштено могу сматрати еквивалентним мерама (Боренштајн и др. 2009). Сви коефицијенти корелације најпре су путем Фишерове $\mathrm{Z}$ трансформације преведени на $z$-вредности. Све даље анализе вршене су на овако фомираним z-вредностима, које су на самом крају конвертоване (помоћу конвертера на сајту Psychometrica.de

1 Такви се показатељи углавном своде на просечну оцену израчунату на основу оцена из матерњег и другог језика, математике, пар природних наука и пар друштвених наука. 
- https://www.psychometrica.de/correlation.html) назад у коефицијенте корелације и пратеће параметре ради приказа резултата (Боренштајн и др. 2009). Израчунат је и одговарајући 95-процентни интервал поверења.

У овој метаанализи определили смо се за модел варијаоилних ефеката (random effects model; Боренштајн и др. 2009). Разлог томе је што су подаци прикупљени из међусобно независних примарних студија спроведених од стране независних истраживача, што свакако не иде у прилог функционалној еквивалентности студија укључених у метаанализу. Испитаници у различитим примарним студијама налазили су се у различитим условима, те би претпоставка о моделу фиксног ефекта (fixed effect model, Боренштајн и др. 2009) у различитим студијама остала непоткрепљена. С друге стране, циљ ове метаанализе јесте генерализација налаза на различите популације, што такође иде у прилог одабиру модела варијабилних ефеката.

\section{РЕЗУЛТАТИ И ДИСКУСИЈА}

У коначној бази података нашла су се 193 примарна извора, од којих је 23 означено као релевантно и подобно за метаанализу $(N=16820)$. Сваки од 23 примарна извора који су били укључени у метаанализу, вођен је истраживачким нацртом корелационо-регресионе природе, а међу њима се налазе четири психометријска рада и две лонгитудиналне студије. Инструмент Grit-S (Дакворт, Квин 2009) је коришћен у 15 студија, док је у преосталих 8 студија употребљен Grit-O (Дакворт и др. 2007). У свим студијама академска успешност је изражена преко просечне оцене или њених деривата.

Од 23 анализиране студије, у 16 студија нађена је позитивна статистички значајна повезаност истрајности и академског постигнућа, док у 7 студија није пронађена статистички значајна повезаност ова два конструкта. У ових 7 студија спада и једна која налази негативну повезаност истрајности и академског постигнућа, али без статистичке значајности. У Табели 1 приказане су још неке информације о 23 студије које су биле укључене у метаанализу.

Табела 1. Информације о студијама укљученим у метаанализу

\begin{tabular}{|c|c|c|c|c|c|}
\hline P. $\delta p$. & Cūyguja & $\begin{array}{c}\text { Мера } \\
\text { исӣирајносӣu }\end{array}$ & 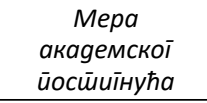 & Узорак & $\begin{array}{l}\text { Главни } \\
\text { налази }\end{array}$ \\
\hline 1. & Карп (2020) & Grit-O скала & $\begin{array}{l}\text { завршна } \\
\text { кумулативна } \\
\text { просечна оцена }\end{array}$ & $\begin{array}{l}168 \text { студената физикалне } \\
\text { терапије (САД) }\end{array}$ & $\begin{array}{l}r=.553 \\
p<.010\end{array}$ \\
\hline 2. & $\begin{array}{l}\text { Кларк, } \\
\text { Малецки } \\
\text { (2019) }\end{array}$ & Grit-S скала & просечна оцена & $\begin{array}{l}757 \text { адолесцената - виши } \\
\text { разреди основних школа у } \\
\text { предграђу (Илиноис, САД) }\end{array}$ & $\begin{array}{l}r=.366 \\
p<.010\end{array}$ \\
\hline
\end{tabular}


Стојадиновић Н. М., Повезаност истрајности и...; УЗДАНИЦА; 2020, XVII/2; стр. 219-232

\begin{tabular}{|c|c|c|c|c|c|}
\hline P. $\delta p$. & Cūyguja & $\begin{array}{c}\text { Мера } \\
\text { исӣирајносӣu }\end{array}$ & 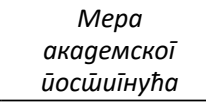 & Узорак & $\begin{array}{l}\text { Главни } \\
\text { налази }\end{array}$ \\
\hline 3. & $\begin{array}{l}\text { Кларк и др. } \\
(2020)\end{array}$ & Grit-S скала & просечна оцена & $\begin{array}{l}1077 \text { ученика из средњих школа } \\
\text { у предграђу (САД) }\end{array}$ & $\begin{array}{l}r=.313 \\
p<.010\end{array}$ \\
\hline 4. & $\begin{array}{l}\text { Кормије, Дан, } \\
\text { Дан (2019) }\end{array}$ & Grit-O скала & просечна оцена & $\begin{array}{l}57 \text { ученика првог разреда } \\
\text { средње школе (Канада) }\end{array}$ & $\begin{array}{l}r=.230 \\
p>.050\end{array}$ \\
\hline 5. & $\begin{array}{l}\text { Кормије, Дан, } \\
\text { Дан (2019) }\end{array}$ & Grit-O скала & просечна оцена & $\begin{array}{l}190 \text { студената-спортиста } \\
\text { (Канада) }\end{array}$ & $\begin{array}{l}r=.180 \\
p<.050\end{array}$ \\
\hline 6. & $\begin{array}{l}\text { Козгроув, Чен, } \\
\text { Кастели (2018) }\end{array}$ & Grit-S скала & $\begin{array}{l}\text { просечна оцена } \\
\text { са државних } \\
\text { тестова из више } \\
\text { предмета }\end{array}$ & $\begin{array}{l}397 \text { адолесцената узраста од } 7 . \\
\text { до 12. разреда (САД) }\end{array}$ & $\begin{array}{l}r=.210 \\
p<.010\end{array}$ \\
\hline 7. & Диксон (2019) & Grit-S скала & $\begin{array}{l}\text { просечна оцена } \\
\text { (самоискази) }\end{array}$ & $\begin{array}{l}1154 \text { адолесцената узраста } \\
\text { од } 10 \text { до } 19 \text { година из урбане } \\
\text { средње школе (САД) }\end{array}$ & $\begin{array}{l}r=.280 \\
p<.001\end{array}$ \\
\hline 8. & $\begin{array}{l}\text { Фленеган, } \\
\text { Ејнарсон } \\
\text { (2017) }\end{array}$ & Grit-S скала & завршна оцена & $\begin{array}{l}169 \text { студената друге године } \\
\text { екологије на истраживачком } \\
\text { универзитету (Канада) }\end{array}$ & $\begin{array}{l}r=.152 \\
p=.100\end{array}$ \\
\hline 9 & $\begin{array}{l}\text { Јачимович и } \\
\text { др. (2018) }\end{array}$ & Grit-S скала & $\begin{array}{l}\text { просечна оцена } \\
\text { из ठазичних } \\
\text { предмета }\end{array}$ & $\begin{array}{l}248 \text { студената са приватног } \\
\text { универзитета (САД) }\end{array}$ & $\begin{array}{l}r=.270 \\
p<.010\end{array}$ \\
\hline 10. & $\begin{array}{l}\text { Јианг и др. } \\
\text { (2019) }\end{array}$ & Grit-S скала & $\begin{array}{l}\text { оцене ученика } \\
\text { на полугодишту } \\
\text { из кинеског, } \\
\text { математике и } \\
\text { енглеског }\end{array}$ & $\begin{array}{l}193 \text { ученика основне школе } \\
\text { (Пекинг) }\end{array}$ & $\begin{array}{l}r=.260 \\
p<.001\end{array}$ \\
\hline 11. & Ли, Сон (2017) & $\begin{array}{l}\text { Grit-O скала } \\
\text { (корејска } \\
\text { верзија) }\end{array}$ & просечна оцена & $\begin{array}{l}235 \text { студената који похађају } \\
\text { курс психологије (Сеул, Јужна } \\
\text { Кореја) }\end{array}$ & $\begin{array}{l}r=.140 \\
p<.050\end{array}$ \\
\hline 12. & $\begin{array}{l}\text { Ли и др. } \\
\text { (2018) }\end{array}$ & Grit-S скала & $\begin{array}{l}\text { просечна стан- } \\
\text { дардизована } \\
\text { оцена изведена } \\
\text { на основу девет } \\
\text { предмета }\end{array}$ & $\begin{array}{l}528 \text { ученика 11. разреда } \\
\text { (Ченгду, Кина) }\end{array}$ & $\begin{array}{l}r=.200 \\
p<.010\end{array}$ \\
\hline 13. & $\begin{array}{l}\text { Ли и др. } \\
\text { (2019) }\end{array}$ & Grit-S скала & $\begin{array}{l}\text { просечна оцена } \\
\text { у првој години }\end{array}$ & $\begin{array}{l}320 \text { студената прве године који } \\
\text { су похађали курс психологије на } \\
\text { државном универзитету (САД) }\end{array}$ & $\begin{array}{l}r=.100 \\
p>.050\end{array}$ \\
\hline 14. & $\begin{array}{l}\text { Лутанс, Лутанс, } \\
\text { Чафин (2019) }\end{array}$ & Grit-S скала & просечна оцена & $\begin{array}{l}176 \text { МБА студената са државног } \\
\text { универзитета (САД) }\end{array}$ & $\begin{array}{l}r=.140 \\
p>.050\end{array}$ \\
\hline 15. & Мејсон (2018) & Grit-O скала & $\begin{array}{l}\text { просечна оцена } \\
\text { на основу пет } \\
\text { предмета }\end{array}$ & $\begin{array}{l}121 \text { студент прве године } \\
\text { природних наука на техничком } \\
\text { факултету (Јужна Африка) }\end{array}$ & $\begin{array}{l}r=.230 \\
p<.010\end{array}$ \\
\hline 16. & $\begin{array}{l}\text { Онил и др. } \\
\text { (2016) }\end{array}$ & Grit-S скала & просечна оцена & $\begin{array}{l}264 \text { латиноамеричких студената } \\
\text { са или без држављанства (САД) }\end{array}$ & $\begin{array}{l}r=.166 \\
p<.050\end{array}$ \\
\hline 17. & $\begin{array}{l}\text { Палисок и др. } \\
\text { (2017) }\end{array}$ & Grit-S скала & просечна оцена & 98 студената фармације (САД) & $\begin{array}{l}r=.190 \\
p=.057\end{array}$ \\
\hline 18. & $\begin{array}{l}\text { Парк и др. } \\
\text { (2018) }\end{array}$ & $\begin{array}{l}\text { Grit-S скала } \\
\text { (одабране } \\
\text { ставке из } \\
\text { корејске } \\
\text { верзије) }\end{array}$ & $\begin{array}{l}\text { стандардизо- } \\
\text { вана просечна } \\
\text { оцена }\end{array}$ & $\begin{array}{l}1277 \text { ученика осмог разреда } \\
\text { (САД) }\end{array}$ & $\begin{array}{l}r=.640 \\
p<.001\end{array}$ \\
\hline
\end{tabular}


Стојадиновић Н. М., Повезаност истрајности и...; УЗДАНИЦА; 2020, XVII/2; стр. 219-232

\begin{tabular}{|c|c|c|c|c|c|}
\hline P. $\delta p$. & Cūyguja & $\begin{array}{c}\text { Мера } \\
\text { исӣирајносӣu }\end{array}$ & 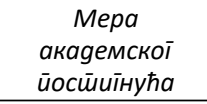 & Узорак & $\begin{array}{l}\text { Главни } \\
\text { налази }\end{array}$ \\
\hline 19. & $\begin{array}{l}\text { Сондерс-Скот, } \\
\text { Брејли, Штен- } \\
\text { Шпидал (2018) }\end{array}$ & Grit-S скала & просечна оцена & $\begin{array}{l}165 \text { студената основних студија } \\
\text { (САД) }\end{array}$ & $\begin{array}{l}r=.020 \\
p>.050\end{array}$ \\
\hline 20. & $\begin{array}{l}\text { Сија и др. } \\
\text { (2018) }\end{array}$ & Grit-O скала & $\begin{array}{l}\text { кумулативна } \\
\text { просечна оцена }\end{array}$ & $\begin{array}{l}389 \text { студената основних студија } \\
\text { (Малезија) }\end{array}$ & $\begin{array}{l}r=.146 \\
p<.010\end{array}$ \\
\hline 21. & $\begin{array}{l}\text { Танг и др. } \\
\text { (2019) }\end{array}$ & Grit-S скала & просечна оцена & $\begin{array}{l}2018 \text { адолесцената од 6. до } 9 . \\
\text { разреда (Финска) }\end{array}$ & $\begin{array}{l}r=.265 \\
p<.010\end{array}$ \\
\hline 22. & $\begin{array}{l}\text { Ворден, } \\
\text { Мајерс (2017) }\end{array}$ & Grit-O скала & просечна оцена & $\begin{array}{l}71 \text { студент изнад } 25 \text { година } \\
\text { старости - „нетрадиционални” } \\
\text { студенти (САД) }\end{array}$ & $\begin{array}{l}r=-.200 \\
p=.090\end{array}$ \\
\hline 23. & $\begin{array}{l}\text { Жисман, } \\
\text { Ганзах (2020) }\end{array}$ & Grit-S скала & просечна оцена & $\begin{array}{l}6748 \text { младих - део } \\
\text { података преузет из студије } \\
\text { NLSY97 спроведене на } \\
\text { репрезентативном узорку од } \\
\text { стране Министарства рада САД }\end{array}$ & $\begin{array}{l}r=.066 \\
p<.010\end{array}$ \\
\hline
\end{tabular}

У Табели 2 приказани су релевантни статистички показатељи у вези са извршеном метаанализом.

Табела 2. Резултати метаанализе - модел варијабилних ефеката

\begin{tabular}{cccccc}
\hline \multicolumn{3}{c}{ Величина ефекта и 95-процентни интервал поверења } & \multicolumn{2}{c}{ Тест нулте хипотезе } \\
\hline Број сйуудија & Меӣасӣайисӣик & Горња іраница & Доња іраница & $Z$ & $p$ \\
\hline 23 & 0.226 & 0.138 & 0.311 & 4.958 & $<0.001$ \\
\hline
\end{tabular}

\section{ЗАКЉУЧАК}

Ово истраживање имало је за циљ метааналитичко испитивање повезаности истрајности и академског постигнућа код ученика различитих узраста, односно ученика различитих нивоа школовања.

Генерално, резултати извршене метаанализе указују на умерену повезаност истрајности и академског постигнућа. Овакав налаз свакако оправдава даља истраживања истрајности као савременог истраживачког конструкта. Ово посебно важи за национални и регионални ниво, где истраживања истрајности још нису у толиком замаху. Међутим, овај општи закључак завређује дубљу разраду. Наиме, све више налаза истраживања спроведених у последњих неколико година показује да компоненте истрајности - конзистентност интересовања и постојаност труда - немају једнаку тежину када је истрајност као дводимензионални конструкт у питању. Односно, у тим истраживањима се показало да би постојаност труда могла имати много већи 
удео у истрајности као целовитом конструкту у односу на конзистентност интересовања. Многи аутори у истраживањима више ни не наводе показатеље величине ефекта везане за истрајност као целовити конструкт, већ само засебне величине ефекта за два наведена предмета мерења. Чак и приликом директне комуникације аутора овог текста са истраживачима истрајности из Европе, Азије и Америке, наглашавана је потреба засебне концептуализације и независног проучавања димензија истрајности поред изучавања истрајности као целовитог конструкта. Мора се признати да проучавање истрајности само као целовитог конструкта јесте слаба тачка ове конкретне метаанализе.

За крај се може издвојити неколико препорука за будуће истраживаче код којих се може пробудити интересовање за испитивање сличне теме: (1) користити статистички софтвер специјализован за метааналитичка истраживања (на пример, Comprehensive Meta-Analysis) како би се избегли многи кораци неопходни приликом коришћења ненаменског софтвера, као у овом случају; (2) укључити докторске дисертације и друге радове који се под одређеним условима могу сматрати ваљаним и поузданим изворима информација за синтетичко истраживање; (3) анализирати ефекат пристрасности објављивања налаза метаанализе помоћу одговарајућих статистичких техника; (4) испитивати засебне ефекте конзистентности интересовања и постојаности труда као компоненти истрајности.

\section{ЛИТЕРАТУРА ${ }^{2}$}

Ал-Мутава, Фател (2018): M. A. Al-Mutawah, M. J. Fateel, Students' achievement in math and science: How grit and attitudes influence?, International Education Studies, 11(2), Thousand Oaks, California: SAGE Publications, 97-105. https://doi.org/10.5539/ ies.v11n2p97

Боренштајн, Хеџис, Хигинс, Ротстајн (2009): M. Borenstein, L. V. Hedges, J. P. T. Higgins, H. R. Rothstein, Introduction to Meta-analysis, Hoboken, New Jersey: John Wiley \& Sons Limited.

Волтерс, Хусеин (2015): С. А. Wolters, M. Hussain, Investigating grit and its relations with college students' self-regulated learning and academic achievement, Metacognition and Learning, 10(3), 293-311. https://doi.org/10.1093/scan/nsw145

* Ворден, Мајерс (2017): D. N. Warden, C. A. Myers, Nonintellective variables and nontraditional college students: A domain-based investigation of academic achievement, College Student Journal, 51(3), Mobile, Alabama: Project Innovation, 380-390.

Дада, Бабатунде, Аделеје (2019): J. O. Dada, S. O. Babatunde, R. O. Adeleye, Assessment of academic stress and coping strategies among built environment undergraduate students in Nigerian higher education, Journal of Applied Research in Higher Education, 11, Bingley: Emerald Publishing, 367-378. https://doi.org/10.1108/JARHE-06-2018-0100

\footnotetext{
${ }^{2}$ Студије означене звездицом (*) укључене су у метаанализу.
} 
Дакворт, Грос (2014): A. L. Duckworth, J. J. Gross, Self-control and grit: Related but separable determinants of success, Current Directions in Psychological Science, 23(5), Thousand Oaks, California: SAGE Publications, 319-325. https://doi. org/10.1177/0963721414541462

Дакворт, Квин (2009): A. L. Duckworth, P. D. Quinn, Development and validation of the Short Grit Scale (Grit-S), Journal of Personality Assessment, 91, Abingdon-onThames: Taylor \& Francis, 166-174. DOI: 10.1080/00223890802634290.

Дакворт, Јигер (2015): A. L. Duckworth, D. S. Yeager, Measurement matters: Assessing personal qualities other than cognitive ability for educational purposes, Educational Researcher, 44(4), Thousand Oaks, California: SAGE Publications, 237-251. https://doi. org/10.3102/0013189X15584327

Дакворт, Питерсон, Метјуз, Кели (2007): A. L. Duckworth, C. Peterson, M. D. Matthews, D. R. Kelly, Grit: Perseverance and passion for long-term goals, Journal of Personality and Social Psychology, 92, Washington: American Psychological Association, 1087-1101. DOI: 10.1037/0022-3514.92.6.1087

Дакворт, Квин, Селиџмен (2009): А. L. Duckworth, P. D. Quinn, M. E. P. Seligman, Positive predictors of teacher effectiveness, The Journal of Positive Psychology, 4, Abingdon-on-Thames: Routledge, 540-547. DOI: 10.1080/17439760903157232

Дату, Валдез (2016): J. А. D. Datu, J. P. M. Valdez, Psychological capital predicts academic engagement and well-being in Filipino highschool students, The Asia-Pacific Education Researcher, 25(3), Berlin: Springer, 399-405. https://doi.org/10.1007/s40299015-0254-1

Дату, Јуен, Чен (2018): J. A. D. Datu, M. Yuen, G. Chen, Exploring determination for long-term goals in a collectivist context: A qualitative study, Current Psychology, 37(1), Berlin: Springer, 263-271. https://doi.org/10.1007/s12144-016-9509-0

* Диксон (2019): D. D. Dixson, Is grit worth the investment? How grit compares to other psychosocial factors in predicting achievement, Current Psychology, 2019, Berlin: Springer, 1-8.

Долек, Лажоа (2018): T. Doleck, S. Lajoie, Social networking and academic performance: A review, Education and Information Technologies, 23, Berlin: Springer, 435465. https://doi.org/10.1007/s10639-017-9612-3

Ејкос, Кречмар (2017): P. Akos, J. Kretchmar, Investigating grit at a non-cognitive predictor of college success, The Review of Higher Education, 40(2), Baltimore, Maryland: Johns Hopkins University Press, 163-186. https://doi.org/10.1353/rhe.2017.0000

* Жисман, Ганзах (2020): C. Zissman, Y. Ganzach, In a Representative Sample Grit Has a Negligible Effect on Educational and Economic Success Compared to Intelligence, Social Psychological and Personality Science, 20(10), Thousand Oaks, California: SAGE Publications, 1-8. https://doi.org/10.1177/1948550620920531

* Јачимович, Вилер, Бејли, Галински (2018): J. М. Jachimowicz, A. Wihler, E. R. Bailey, A. D. Galinsky, Why grit requires perseverance and passion to positively predict performance, Proceedings of the National Academy of Sciences, 115(40), Washington: United States National Academy of Sciences, 9980-9985.

* Јианг, Сјао, Лиу, Ђианг, Ду (2019): W. Jiang, Z. Xiao, Y. Liu, K. Guo, J. Jiang, $\mathrm{X}$. Du, Reciprocal relations between grit and academic achievement: A longitudinal study, Learning and Individual Differences, 71, Amsterdam: Elsevier, 13-22. 
Јигер, Волтон (2011): D. S. Yeager, G. M. Walton, Social-psychological interventions in education: They're not magic, Review of Educational Research, 81(2), Berlin: Springer, 267-301. https://doi.org/10.3102/0034654311405999

* Карп, Фрај, Гумерман, Пресли, Витман (2020): S. Carp, K. Fry, B. Gumerman, K. Pressley, A. Whitman, Relationship Between Grit Scale Score and Academic Performance in a Doctor of Physical Therapy Program: A Case Study, Journal of Allied Health, 49(1), Washington: Association of Schools Advancing Health Professions, 29-36.

Кели, Таунсенд, Дејвис, Нуријан, Бостром, Феликс (2018): A. M. Kelly, K. W. Townsend, S. Davis, L. Nouryan, M. P. Bostrom, K. J. Felix, Comparative assessment of grit, conscientiousness, and self-control in applicants interviewing for residency positions and current orthopaedic surgery residents, Journal of Surgical Education, 75(3), Amsterdam: Elsevier, 557-563.

* Кларк, Малецки (2019): К. N. Clark, С. К. Malecki, Academic Grit Scale: Psychometric properties and associations with achievement and life satisfaction, Journal of School Psychology, 72, Amsterdam: Elsevier, 49-66. https://doi.org/10.1016/j.jsp.2018.12.001

* Кларк, Дорио, Елдриџ, Малецки, Демари (2020): К. N. Clark, N. B. Dorio, M. A. Eldridge, C. K. Malecki, M. K. Demaray, Adolescent academic achievement: A model of social support and grit, Psychology in the Schools, 57(2), Hoboken, New Jersey: Wiley-Blackwell, 204-221.

* Козгроув, Чен, Кастели (2018): J. M. Cosgrove, Y. T. Chen, D. M. Castelli, Physical fitness, grit, school attendance, and academic performance among adolescents, $B i$ oMed Research International, 2018, London: Hindawi Publishing Corporation, 1-7. https:// doi.org/10.1155/2018/9801258

* Кормије, Дан, Дан (2019): D. L. Cormier, J. G. Dunn, J. C. Dunn, Examining the domain specificity of grit, Personality and Individual Differences, 139, Amsterdam: Elsevier, 349-354.

Крид, Тинан, Хармс (2017): M. Credé, M. C. Tynan, P. D. Harms, Much ado about grit: A meta-analytic synthesis of the grit literature, Journal of Personality and Social Psychology, 113(3), Washington: American Psychological Association, 492-511. https:// doi.org/10.1037/pspp0000102

Кристенсен, Кнезек (2014): R. Christensen, G. Knezek, Comparative measures of grit, tenacity and perseverance, International Journal of Learning, Teaching and Educational Research, 8(1), Mauritius: Society for Research and Knowledge Management, 16-30.

Лам, Жу (2019): K. K. L. Lam, M. Zhou, Examining the relationship between grit and academic achievement within K-12 and higher education: A systematic review, Psychology in the Schools, 56(10), Hoboken, New Jersey: Wiley-Blackwell, 1654-1686.

* Ли, Сон (2017): S. Lee, Y. W. Sohn, Effects of grit on academic achievement and career-related attitudes of college students in Korea, Social Behavior and Personality: an International Journal, 45(10), New Zealand: Scientific Journal Publishers Limited, 1629-1642.

* Ли, Жао, Конг, Ду, Јанг, Ванг (2018): J. Li, Y. Zhao, F. Kong, S. Du, S. Yang, S. Wang, Psychometric assessment of the short grit scale among Chinese adolescents, Journal of Psychoeducational Assessment, 36(3), Thousand Oaks, California: SAGE Publications, 291-296. https://doi.org/10.1177/0734282916674858

* Ли, Шелдон, Роудер, Бергин, Гири (2019): Y. Li, К. M. Sheldon, J. N. Rouder, D. A. Bergin, D. C. Geary, Long-term prospects and college students' academic perfor- 
mance, Journal of Psychoeducational Assessment, 37(3), Thousand Oaks, California: SAGE Publications, 358-371.

* Лутанс, Лутанс, Чафин (2019): K. W. Luthans, B. C. Luthans, T. D. Chaffin, Refining grit in academic performance: The mediational role of psychological capital, Journal of Management Education, 43(1), Thousand Oaks, California: SAGE Publications, 35-61.

Мади, Ервин, Кармоди, Виљареал, Вајт, Гундерсен (2013): S. R. Maddi, L. M. Erwin, C. L. Carmody, B. J. Villarreal, M. White, K. K. Gundersen, Relationship of hardiness, grit, and emotional intelligence to internet addiction, excessive consumer spending, and gambling, The Journal of Positive Psychology, 8, Abingdon-on-Thames: Routledge, 128-134. DOI: 10.1080/17439760.2012.758306.

* Мејсон (2018): H. D. Mason, Grit and academic performance among first-year university students: A brief report, Journal of Psychology in Africa, 28(1), Abingdon-onThames: Taylor \& Francis, 66-68.

Метерн, Шо (2010): K. D. Mattern, E. J. Shaw, A look beyond cognitive predictors of academic success: Understanding the relationship between academic self-beliefs and outcomes, Journal of College Student Development, 51(6), Baltimore, Maryland: Johns Hopkins University Press, 665-678. https://doi.org/10.1353/csd.2010.0017

Муенкс, Вигфилд, Јанг, О’Нил (2017): K. Muenks, A. Wigfield, J. S. Yang, C. R. O'Neal, How true is grit? Assessing its relations to high school and college students' personality characteristics, self-regulation, engagement, and achievement, Journal of Educational Psychology, 109(5), Washington: American Psychological Association, 599-620. https:// doi.org/10.1037/edu0000153

* O’Нил, Еспино, Голтрајт, Морин, Вестон, Хернандес, Фурман (2016): C. R. O’Neal, M. M. Espino, A. Goldthrite, M. F. Morin, L. Weston, P. Hernandez, A. Fuhrmann, Grit under duress: Stress, strengths, and academic success among non-citizen and citizen Latina/o first-generation college students, Hispanic Journal of Behavioral Sciences, 38(4), Thousand Oaks, California: SAGE Publications, 446-466.

Ориол, Миранда, Ојанедел, Торес (2017): X. Oriol, R. Miranda, J. C. Oyanedel, J. Torres, The role of self-control and grit in domains of school success in students of primary and secondary school, Frontiers in Psychology, 8, Lausanne: Frontiers Media, 1-9. https://doi.org/10.3389/fpsyg.2017.01716

Остин, Саклофски, Масторас (2010): E. Austin, D. Saklofske, S. Mastoras, Emotional intelligence, coping and exam-related stress in Canadian undergraduate students, Australian Journal of Psychology, 62(1), New York City: Wiley, 42-50. https://doi. org/10.1080/00049530903312899

* Палисок, Мацумото, Хо, Пери, Танг, Ип (2017): A. J. L. Palisoc, R. R. Matsumoto, J. Ho, P. J. Perry, T. T. Tang, E. J. Ip, Relationship between grit with academic performance and attainment of postgraduate training in pharmacy students, American Journal of Pharmaceutical Education, 81(4), Arlington, Virginia: American Association of Colleges of Pharmacy, ar. 67.

* Парк, Ју, Белен, Цукајама, Дакворт (2018): D. Park, A. Yu, R. N. Baelen, E. Tsukayama, A. L. Duckworth, Fostering grit: Perceived school goal-structure predicts growth in grit and grades, Contemporary Educational Psychology, 55, Amsterdam: Elsevier, $120-128$.

Ричардсон, Ејбрехем, Бонд (2012): M. Richardson, C. Abraham, R. Bond, Psychological correlates of university students' academic performance: a systematic review 
and meta-analysis, Psychological Bulletin, 138(2), Washington: American Psychological Association, 353.

* Сија, Онг, Нгиам, Тан (2018): Р. С. Siah, Р. J. М. Ong, S. J. Ngiam, J. Т. А. Tan, The mediating effect of grit on sleep quality and academic performance among undergraduates in Malaysia, Journal of Institutional Research South East Asia, 16(1), Kuala Lumpur: SEAAIR.

* Сондерс-Скот, Брејли, Штен-Шпидал (2018): D. Saunders-Scott, M. B. Braley, N. Stennes-Spidahl, Traditional and psychological factors associated with academic success: investigating best predictors of college retention, Motivation and Emotion, 42(4), Berlin: Springer, 459-465.

Сохејл (2013): N. Sohail, Stress and academic performance among medical students, Journal of the College of Physicians and Surgeons, 23(1), Karachi, Pakistan: Secretary, College of Physicians and Surgeons, 67-71.

Сузуки, Тамесу, Асахи, Ишикава (2015): Y. Suzuki, D. Tamesue, K. Asahi, Y. Ishikawa, Grit and Work Engagement: A Cross-Sectional Study, PLoS ONE, 10(9), San Francisco: Public Library of Science, e0137501. https://doi.org/10.1371/journal. pone. 0137501

* Танг, Ванг, Гуо, Салмела-Аро (2019): X. Tang, M. T. Wang, J. Guo, K. SalmelaAro, Building grit: The longitudinal pathways between mindset, commitment, grit, and academic outcomes, Journal of Youth and Adolescence, 48(5), Berlin: Springer, 850-863.

* Фленеган, Ејнарсон (2017): К. М. Flanagan, J. Einarson, Gender, math confidence, and grit: Relationships with quantitative skills and performance in an undergraduate biology course, CBE - Life Sciences Education, 16(3): ar47, Bethesda, Maryland: American Society for Cell Biology.

Фук, Сиду (2015): С. Y. Fook, G. K. Sidhu, Investigating learning challenges faced by students in higher education, Procedia - Social and Behavioral Sciences, 186, Amsterdam, Elsevier, 604-612. https://doi.org/10.1016/j.sbspro.2015.04.001

Хоџ, Рајт, Бенет (2018): В. Hodge, B. Wright, P. Bennett, The role of grit in determining engagement and academic outcomes for university students, Research in Higher Education, 59(4), Berlin: Springer, 448-460. https://doi.org/10.1007/s11162-017-9474-y

Хуанг, Лим, Ха (2017): M. H. Hwang, H. J. Lim, H. S. Ha, Effects of grit on the academic success of adult female students at Korean Open University, Psychological Reports, 121(4), Thousand Oaks, California: SAGE Publications, 705-725. https://doi. org/10.1177/0033294117734834

Чен (2018): C. Chen, Grit, Intrinsic motivation, and costly perseverance: Their interactive influence in problem solving, Proceedings of the National Conference on Undergraduate Research, Edmond, Oklahoma.

Штурман, Запала-Пиеме (2017): E. D. Sturman, K. Zappala-Piemme, Development of the grit scale for children and adults and its relation to student efficacy, test anxiety, and academic performance, Learning and Individual Differences, 59, Amsterdam: Elsevier, 1-10. https://doi.org/10.1016/j.lindif.2017.08.004 
Miloš N. Stojadinović

University of Niš

Faculty of Philosophy

Department of Psychology

PhD student

\section{RELATIONSHIP BETWEEN GRIT AND ACADEMIC ACHIEVEMENT: A META-ANALYSIS}

Summary: In recent years, grit attracts attention of researchers as well as practitioners within developmental and educational psychology branches. Grit has shown to be an important noncognitive predictor of academic achievement, as well as achievement in other life contexts. However, empirical evidence is often nonconsistent regarding the relationship between grit and academic achievement. The aim of this study is to synthesise the empirical findings regarding the relationship between grit and academic achievement. Twenty-three relevant studies $(N=16820)$ satisfied the criteria for inclusion in the meta-analysis. Statistical analysis using random effects model suggests there is a moderate correlation between grit and academic achievement ( $r=.226$ [CI: .138; .311], $Z=4.958, p<.001)$.

Keywords: grit, academic achievement, meta-analysis. 